\title{
STRUCTURAL LINKAGE OF MAJOR TECTONIC ELEMENTS IN THE UGASHIK-BECHAROF LAKES REGION, NORTHEASTERN ALASKA PENINSULA
}

\author{
by \\ Paul L. Decker ${ }^{1}$, Rocky R. Reifenstuhl², and Robert J. Gillis²
}

\begin{abstract}
In the Ugashik Lakes-Becharof Lake region of the Alaska Peninsula, the northeastern end of the North Aleutian basin approaches the southernmost outcrops of the upthrown block of the regional Bruin Bay fault. Subsidence in this segment of the Tertiary backarc was probably in part coeval with reverse or reverse-oblique uplift along the Bruin Bay fault system, but details of the spatial and temporal interaction between these features are not well documented. This report identifies three previously unnamed tectonic elements that are important in clarifying the region's tectonic history: the Ugashik sub-basin, the Ugashik Lakes fault system, and the Becharof discontinuity. The Ugashik sub-basin is the northeastern segment of the North Aleutian backarc basin, separated from the main basin by a major Eocene-Oligocene extrusive complex in the Port Heiden area. The sub-basin is further distinguished by the timing of the onset of major subsidence, best expressed by differential thickening of the Miocene Bear Lake Formation. This significantly postdates the Eocene or older onset of subsidence recorded by the Tolstoi Formation in the heart of the backarc basin to the southwest near Port Moller. The Ugashik sub-basin is bounded on the southeast by the Ugashik Lakes fault system, a northeast-trending set of down-to-northwest faults mapped previously from limited outcrop information. The northeast margin of the sub-basin is the Becharof discontinuity, a northwest-trending zone of crustal weakness interpreted from geophysical data, volcanic activity, and modern seismicity. Focal mechanism solutions from the region are consistent with largely strike-slip motion in a present-day stress regime dominated by a nearly north-south-trending, subhorizontal axis of maximum compressive stress. Assuming similar stress orientations during Neogene time, subsidence of the Ugashik sub-basin may represent a local transtensional response to sinistral displacement along the Ugashik Lakes fault system, possibly contemporaneous with transpressional uplift on the Bruin Bay fault farther north. Additional studies of the timing, sense, and magnitude of Bruin Bay fault displacement will provide valuable constraints on this hypothesis.
\end{abstract}

\section{INTRODUCTION}

This report attempts to clarify the timing and mechanisms of subsidence in the northeastern part of the North Aleutian basin beneath the Ugashik and Becharof Lakes region of the Alaska Peninsula (fig. 1). We devote particular emphasis to a set of faults in the Ugashik Lakes area that likely represent the largely concealed tectonic boundary separating the Tertiary-aged North Aleutian backarc basin to the northwest from the structurally elevated belt of Jurassic and older strata along the Pacific coast on the southeast. We also speculate on the nature of the equally cryptic boundary that separates the northeast end of the backarc basin from the arc batholith and metamorphic basement that makes up the upthrown northwestern block of the Bruin Bay fault. Drawing on new field observations, legacy geologic mapping, well correlations, and newly interpreted aeromagnetic data, seismic surveys, and earthquake focal mechanism solutions, we describe major tectonic elements in the region, and present a simple model of their possible kinematic interactions during late Tertiary time. This hypothesis may have significant implications with respect to hydrocarbon exploration within the basin and the broader tectonic history of southwestern Alaska.

\section{MAJOR TECTONIC ELEMENTS}

Several major tectonic elements are central to this report, including the Bruin Bay fault and three previously unnamed features: the Ugashik Lakes fault system, the Ugashik sub-basin, and the Becharof discontinuity. We briefly introduce these elements here before moving on to provide a more in-depth description and interpretation of the Ugashik Lakes fault system, and conclude by incorporating all the major elements into a Neogene kinematic model.

\section{BRUIN BAY FAULT}

The northeast-trending Bruin Bay fault (Detterman and Hartsock, 1966; Detterman and others, 1976; Detterman and Reed, 1980; Detterman and others, 1987) is among the major structures of southern Alaska. It constitutes a system of several fault strands that extends some $515 \mathrm{~km}$ (320 miles) (Detterman and others, 1976) from at least Becharof Lake (fig. 1A) to its intersection with the Castle Mountain fault, the northern margin of the upper Cook Inlet basin. On the west side of lower Cook Inlet, the Bruin Bay fault has been shown to have up-to-northwest reverse stratigraphic separation of more than 3,000 $\mathrm{m}(10,000 \mathrm{ft})$, and possible left-lateral

${ }^{1}$ Alaska Division of Oil \& Gas, 550 W. 7th Ave., Suite 800, Anchorage Alaska 99501-3560

${ }^{2}$ Alaska Division of Geological \& Geophysical Surveys, 3354 College Rd., Fairbanks, Alaska 99709-3707 
movement of 10 to $19 \mathrm{~km}$ (6-12 mi; Detterman and Hartsock, 1966; Detterman and others, 1976). Major movement on the Bruin Bay fault system is thought to have occurred during middle to late Tertiary time, ending in the Miocene (Detterman and Reed, 1980). It may have been responsible for uplift and erosion of the Alaska-Aleutian Range batholith as early as the Late Jurassic, coincident with the deposition of arkosic sandstones and granitic conglomerates of the Naknek Formation (fig. 2; Detterman and Reed, 1980, p. B71). The southern limit of the Bruin Bay fault trace has been plotted differently on various geologic maps. Wilson and others (1999) ended the fault beneath Becharof Lake (fig. 1B). Detterman and others (1987) speculated that the Bruin Bay fault extends much farther southwest in the subsurface, following an aeromagnetic anomaly pattern that we believe relates more directly to the Ugashik Lakes fault system (fig. 3).

\section{UGASHIK LAKES FAULT SYSTEM}

A north-northeast-trending fault zone, referred to here as the Ugashik Lakes fault system (ULFS, figs. 1B and 3), is constrained by outcrop relationships at just two localities. These locations are approximately $21 \mathrm{~km}$ (13 mi) apart, located north and south of Lower Ugashik Lake (Detterman and others, 1987; Wilson and others, 1999). This fault system juxtaposes a large region of broadly folded and highly faulted Jurassic Naknek Formation and older rocks on the east with limited exposures of Tertiary Bear Lake Formation, the northeastern-most exposures of the North Aleutian backarc basin (figs. 1A and 2). Relative ages clearly indicate the northwestern side of the ULFS is downthrown in a relative sense. However, fault attitudes and kinematics have not been documented previously; normal, reverse, strike-slip, and/or reactivational displacements along this system are all permissible interpretations of the fault patterns as represented on legacy geologic maps. Much of this report pertains to our observations and interpretations

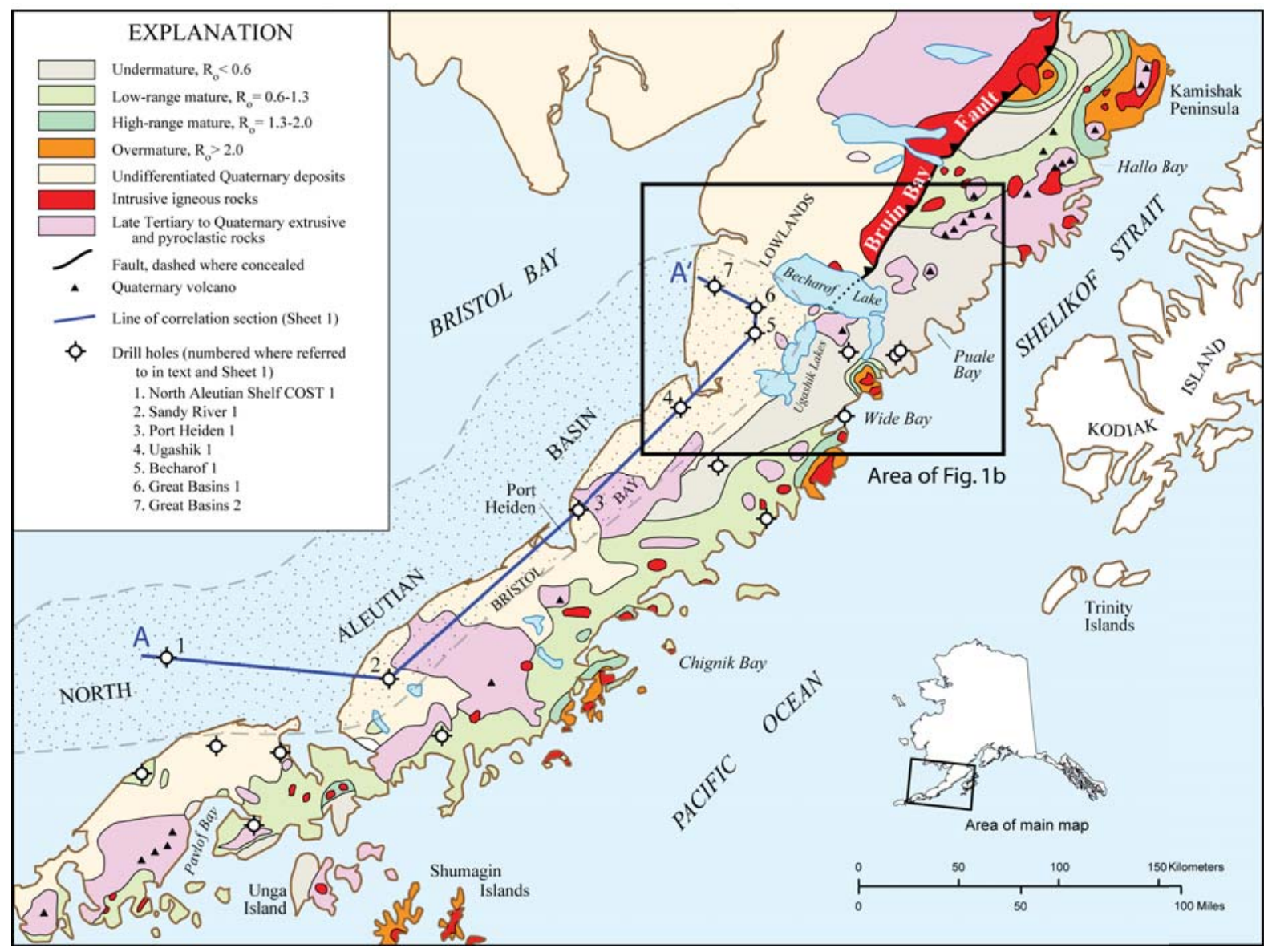

Figure 1A. Location map of the Alaska Peninsula, modified from surface thermal maturity map of Molenaar (1996). Inset shows area of this study, shown in more detail in geologic map, figure 1B. Note line of section A-A'(sheet 1) through numbered wells, approximate outline of North Aleutian basin, Becharof Lake, Ugashik Lakes, and the Bruin Bay fault. 
of the ULFS relative to the mapped formation boundaries shown in figure 3 (Detterman and others, 1987) and to the northeast-trending, relatively short-wavelength aeromagnetic anomalies shown in figure 4 (Saltus and others, 1999; Meyer and others, 2004; Meyer, 2007).

\section{UGASHIK SUB-BASIN}

Interpretation of subsurface well and seismic data, in conjunction with aeromagnetic and surface geologic mapping, strongly suggests the presence of a faultcontrolled Neogene depocenter beneath the Bristol Bay lowlands west of Ugashik Lakes and southwest of Becharof Lake. As shown in the regional well log correlation panel of Sheet 1, sedimentary strata of the Ugashik sub-basin are separated from the main backarc depocenter to the southwest by a thick, extensive sequence of Meshik Formation lavas penetrated in the Port Heiden 1 and Ugashik 1 wells. Sherwood and others
(2006, p. 20) recognized this segmentation of the North Aleutian basin and interpreted the intervening Meshik sequence as a massive Eocene to Oligocene extrusive complex. Figure 5 shows a time-structure interpretation at or near the base of the Bear Lake Formation from publicly released two-dimensional (2-D) seismic data. A variety of fault trends are interpreted to have accommodated differential subsidence within the sub-basin. Evidence that the Ugashik sub-basin has a younger subsidence history than the southern part of the North Aleutian basin is presented in context of our Neogene tectonic model later in this report.

\section{BECHAROF DISCONTINUITY}

Several independent lines of evidence suggest that an important and previously unrecognized crustal boundary cuts across the Alaska Peninsula trending northwest near the south shore of Becharof Lake. Referred to here as the

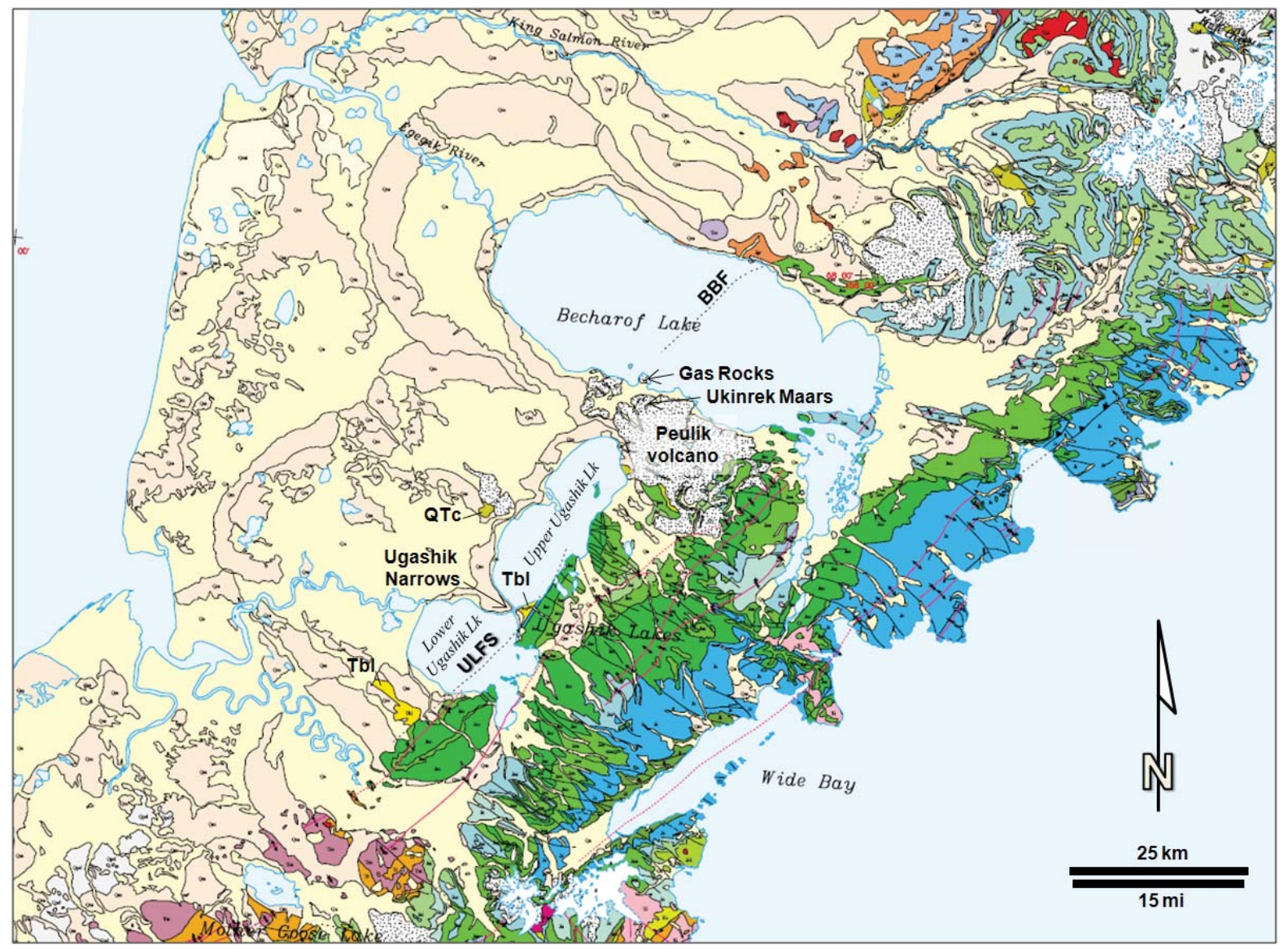

Figure 1B. Excerpt from regional geologic map of Wilson and others (1999) with labels of geologic and geographic features added for visibility. The northeasternmost exposures of Miocene Bear Lake Formation (darkyellow, Tbl) occur in the Ugashik Narrows area (between Upper and Lower Ugashik Lakes) and south of Lower Ugashik Lake, where they are juxtaposed by faults of the down-to-west Ugashik Lakes fault system (ULFS) with Jurassic Shelikof (blue) and Naknek (various shades of green) Formations to the southeast. Quaternary or Tertiary contact metamorphic unit (greenish-yellow, QTc) west of Upper Ugashik Lake is labeled here to avoid confusion with Bear Lake Formation. 
Becharof discontinuity, this boundary can be observed in the unfiltered aeromagnetic data (fig. 4). In the lowlands west of the lake, the Becharof discontinuity manifests as a broad magnetic gradient. On the northeast is an area of high magnetic intensity corresponding to the uplifted arc-batholith basement in the hangingwall of the Bruin Bay fault (the Iliamna subterrane of Wilson and others [1985]). To the southwest is an area of low magnetic intensity corresponding to the sediment-filled Ugashik sub-basin. Interpretation near the base of the sedimentary section in the northeastern part of the sub-basin reveals a set of down-to-southwest Neogene faults that parallel the contours of this magnetic gradient (figs. 4 and 5). Hence, the magnetic gradient corresponds to the structural gradient on the top of the basement complex.

The Becharof discontinuity has a different magnetic expression beneath southern Becharof Lake itself, where banded, short wavelength anomalies with distinctly

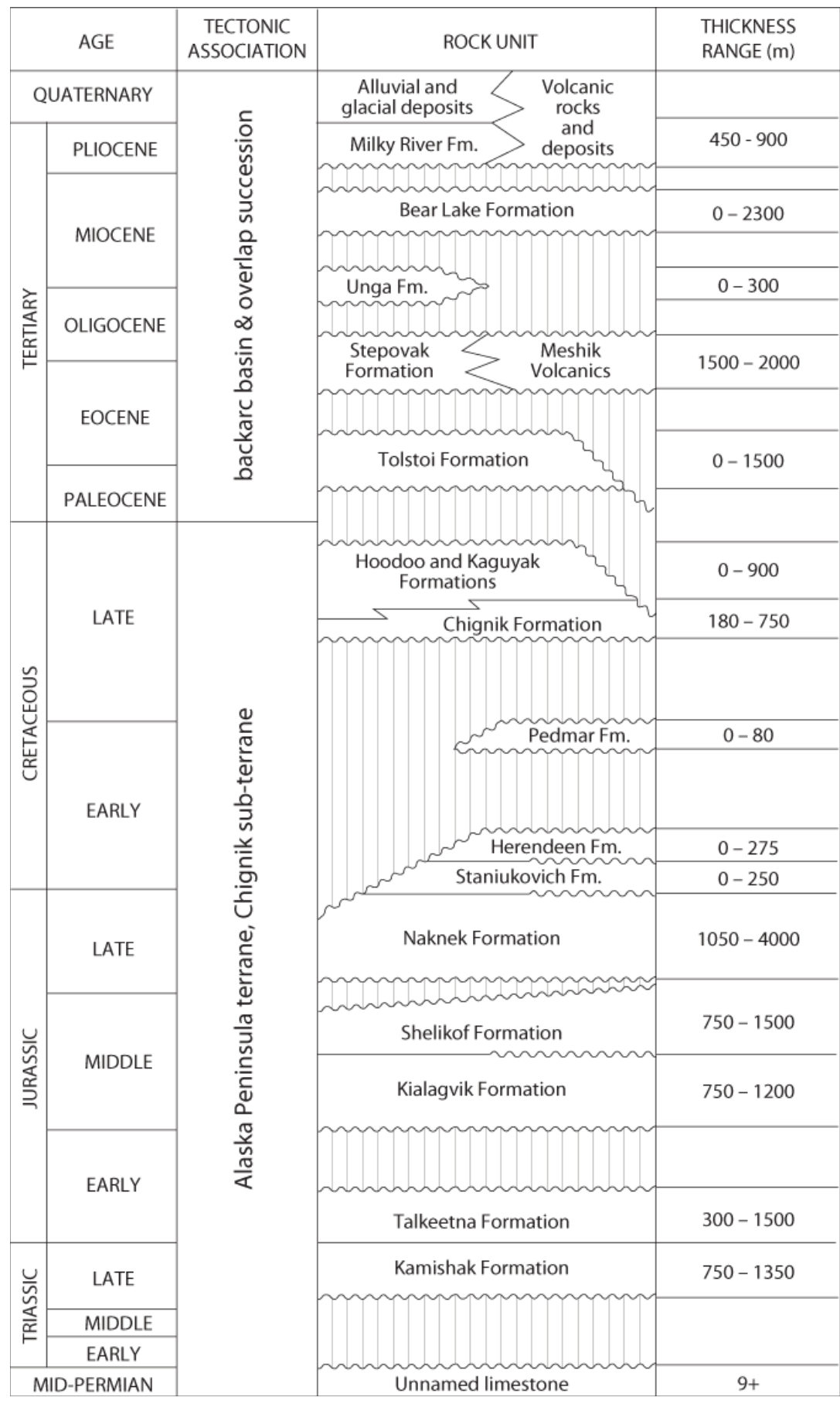

Figure 2. Composite stratigraphic column for the Alaska Peninsula, modified after Beeman and others (1996) and Detterman and others (1996). Metamorphic and plutonic units, including the Iliamna sub-terrane of the Alaska Peninsula terrane, are not depicted. 
different trends approach from either side and terminate near the south shore of the lake. The linear anomalies on the north side are clearly related to the Bruin Bay fault, whereas we relate the more arcuate southern anomalies to the ULFS, as discussed in more detail below. Their point of intersection coincides closely with the prolific vents of mantle-derived carbon dioxide at Gas Rocks (fig. 1B; Symonds and others, 1997). Close by are the Ukinrek Maars, two craters formed in 1977 by mantlelinked phreatomagmatic eruptions (Barnes and McCoy, 1979; Motyka and others, 1993). A swarm of strong, shallow earthquakes recorded during May to October
1998 was concentrated beneath the western part of Becharof Lake along the same discontinuity (McGimsey and others, 2003). Considered along with evidence of recent inflation of Mount Peulik volcano located on the same trend immediately to the southeast (fig. 1B; C. Nye, written commun., January 18, 2007), these observations suggest that the Becharof discontinuity marks a persistent zone of weakness in the upper lithosphere that may remain active today. This zone is tectonically significant because it may explain the decoupling of the Bruin Bay fault from the Ugashik Lakes fault system, allowing uplift to the north and subsidence to the south.

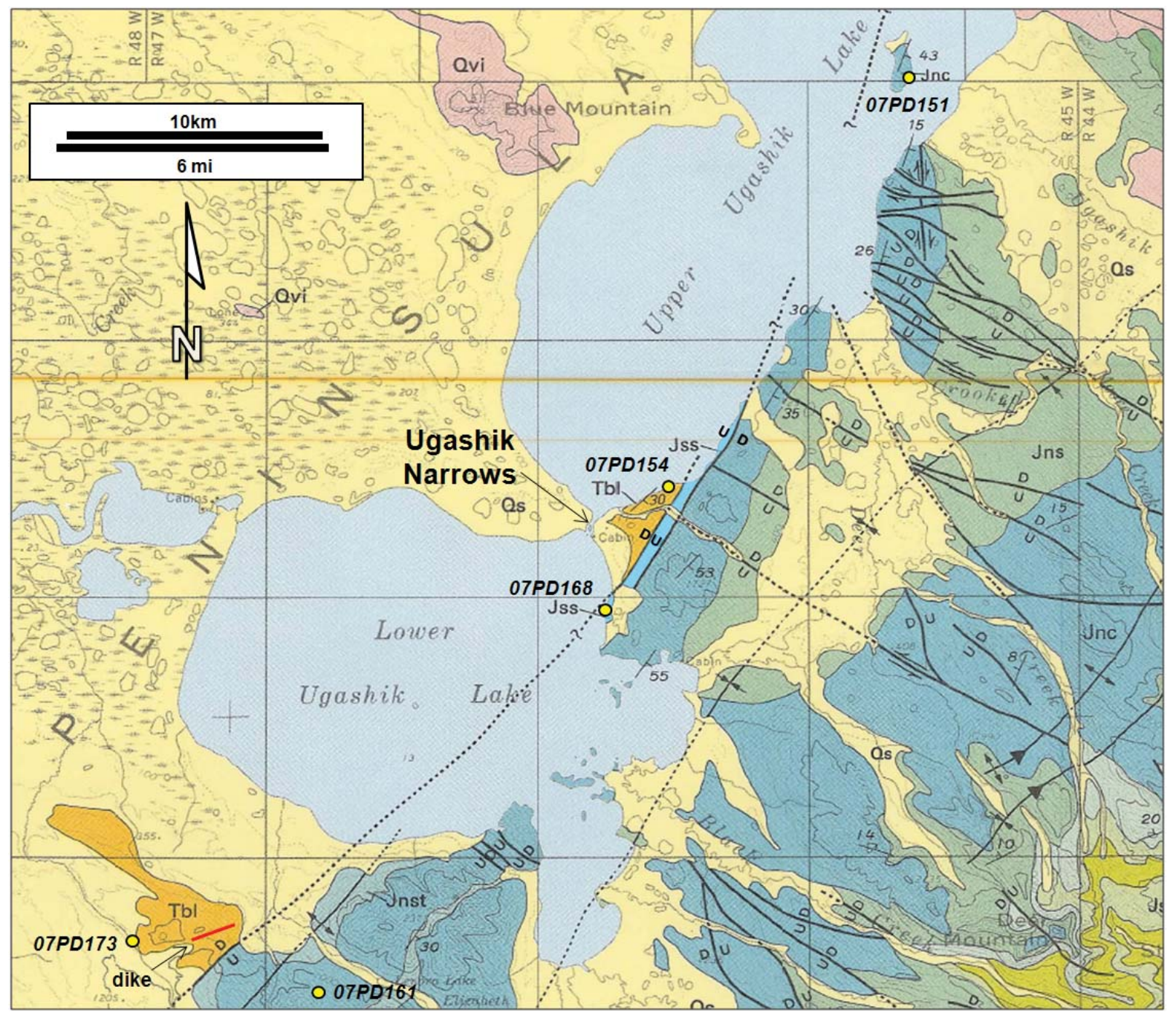

Figure 3. Excerpt from 1:250,000-scale geologic map adapted from Detterman and others (1987) showing key outcrop relationships in the Ugashik Lakes area. Relevant unit abbreviations: Bear Lake Formation (Tbl), Naknek Formation (Jnc, Jnst, Jns), and Shelikof Formation (Jss). Yellow dots labeled in italics are stations with structural fabric measurements shown in figure 10. Also added to map is the trace of a previously unmapped dike southwest of Lower Ugashik Lake, discussed in text. 


\section{INVESTIGATIONS OF THE UGASHIK LAKES FAULT SYSTEM}

Prior to conducting field work in the Ugashik Lakes area, we recognized the Ugashik sub-basin and speculated as to the existence of the Becharof discontinuity. We hypothesized that the ULFS represents at least two major, down-to-west normal or normal-oblique faults that helped accommodate Neogene subsidence and sedimentation in the Ugashik sub-basin. The map traces of these controlling faults, including their covered reaches, were predicted to correspond closely with the arcuate bands of the short-wavelength aeromagnetic anomaly observed in the (unfiltered) total field aeromagnetic data (fig. 4). An important part of this study is to test this hypothesis by (1) field checking outcrop relationships presented in legacy geologic maps, (2) relating those field relationships to aeromagnetic boundaries, and (3) collecting outcrop structural data relevant to interpreting the attitude, kinematics, and movement history of the main fault or faults that make up the system. The following discussion presents our findings in each of these three areas.

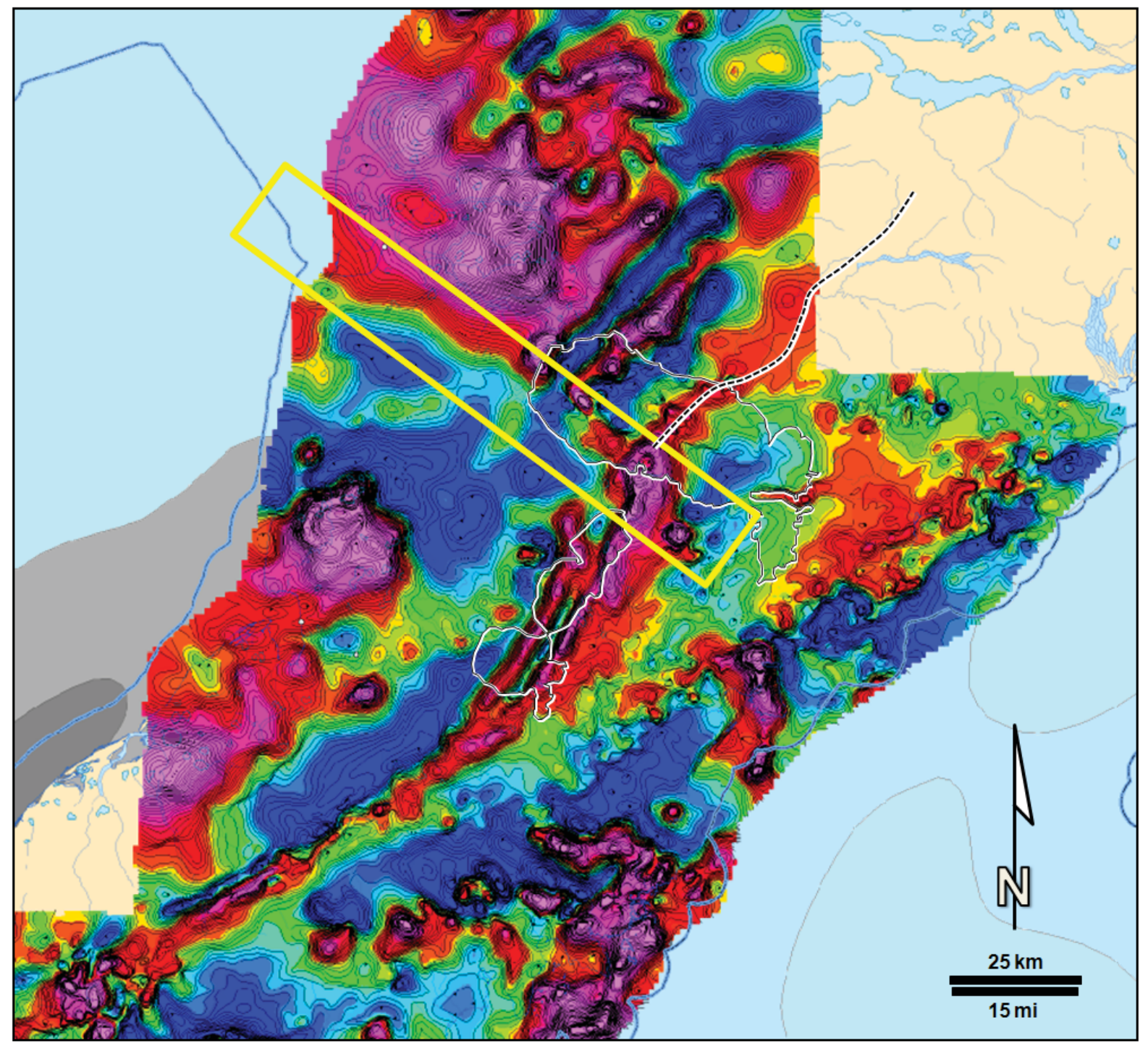

Figure 4. Total field aeromagnetic anomaly of the region surrounding Becharof Lake and the Ugashik Lakes (overlaid for geographic reference in black and white lines), excerpted and modified from Meyer (2007), after Meyer and others (2004) and Saltus and others (1999). Warm colors (violet, red, orange, and yellow) are positive magnetic anomalies; cool colors (greens and blues) are negative magnetic anomalies. Yellow rectangle marks the Becharof magnetic discontinuity referred to in text; dashed black line is the trace of the Bruin Bay fault from Wilson and others (1999). 


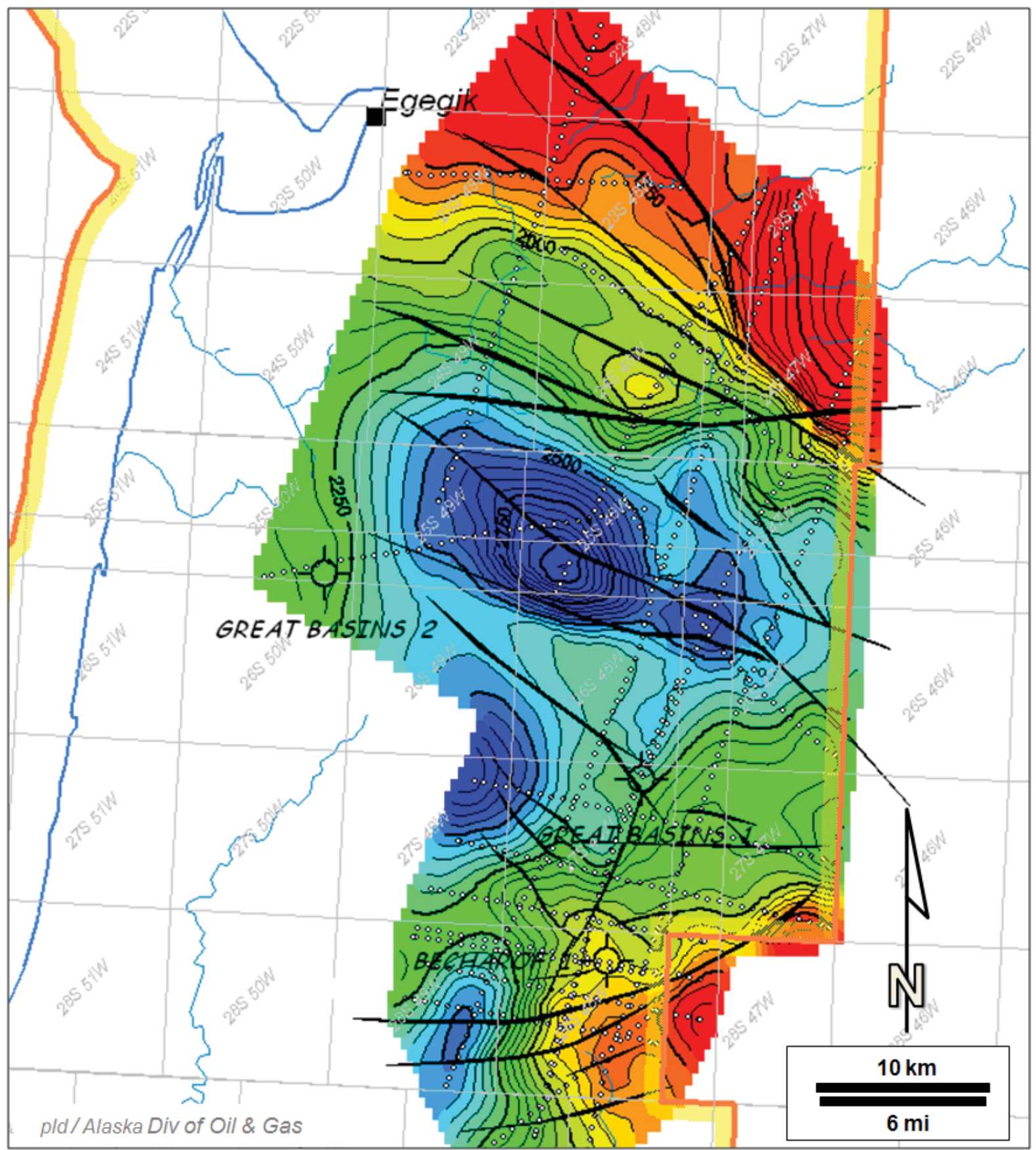

Figure 5. Preliminary time-structure interpretation near the base of the Bear Lake Formation from publicly available seismic data in the western part of the Ugashik sub-basin, west of Becharof Lake. West-northwest-trending faults appear to control subsidence from the structurally highest area along the Becharof discontinuity in the north (red) into the structurally lowest part of the sub-basin (blue). Contour interval: 50 milliseconds two-way time. Seismic lines are shown by small white circles (shotpoints). Orange and yellow border marks Alaska Peninsula areawide lease sale boundary. Refer to figure 8 for location relative to geologic map. 


\section{LEGACY MAPPING AND OUTCROP RELATIONSHIPS}

Without recognizing the magnetic contrasts and other criteria cited above that define the Becharof discontinuity, Detterman and others (1987) cited aeromagnetic data in suggesting that the Bruin Bay fault continues in the subsurface far to the southwest beyond Ugashik Lakes. Wilson and others (1999) later adopted a more restrictive view, ending the trace near the middle of Becharof Lake, thus setting the Bruin Bay fault apart from the ULFS as we describe it. Detterman and others (1987) initially mapped the Bruin Bay fault with a continuous queried line some $30 \mathrm{~km}(20 \mathrm{mi})$ farther south into Upper Ugashik Lake, where they show it in cross section as a west-dipping normal fault. They offered no explanation of how or why this major fault's reverse movement would transition laterally into major normal displacement across Becharof Lake. Nor did they present evidence that the fault dips to the west in the Ugashik Lakes area, presumably making the assumption that the fault maintains the same general attitude as the Bruin Bay fault to the north. Nonetheless, because we realized that major structural changes might occur across the Becharof discontinuity, we sought field evidence to evaluate other possible fault orientations. For example, might the faults at Ugashik Lakes consist of northwestverging reverse or thrust faults linked to compressional deformation of the Mesozoic rocks to the east? Alternatively, could the faults be nearly vertical and have substantial strike-slip displacement?

In the immediate vicinity of Ugashik Lakes, our field observations confirmed the general distribution of rock units as mapped (fig. 3; Detterman and others, 1987), including the close juxtaposition of Jurassic and Tertiary formations (see outcrop photos of key units in figure 6). However, in many places, actual outcrop is far less extensive and surficial cover is more extensive than shown. The area of Bear Lake outcrop is heavily overrepresented in previous mapping, both near the Ugashik Narrows (the small stream connecting Upper and Lower Ugashik lakes, figs. 1B and 3) and in the upland area south of Lower Ugashik Lake. However, we did locate an additional Bear Lake outcrop immediately northwest of the Narrows where the shoreline was previously mapped as Quaternary. Overall, we believe the bedrock units mapped by Detterman and others (1987) near the ULFS are mostly accurately portrayed, even if the area of their outcrop is simplified.

Unfortunately, our field investigations revealed no exposures of the surfaces of the controlling faults of the ULFS. Although Detterman and others (1987) and Wilson and others (1999) mapped the ULFS with solid lines near Ugashik Narrows and in the uplands south of Lower Ugashik Lake, our investigations found the faults to be universally covered by either surficial deposits, dense vegetation, or the lakes themselves. This lack of exposure leaves considerable uncertainty regarding the number, attitude, sense of movement, and cumulative displacement of the major faults in this zone. Minor faults, shear joints, and fractures are abundant in some exposures near the mapped fault traces, and provide at least some basis for inferring the attitude of the associated major faults. We present and interpret outcrop fabric data in a subsequent section below.

Our work corroborates other key geologic map relationships shown in figure 3 that are relevant to integrating the aeromagnetic data into the structural interpretation of the ULFS. The island in the northern part of Upper Ugashik Lake and most of the eastern shoreline of the Ugashik Lakes are underlain by moderately east-dipping conglomerates and sandstones of the Upper Jurassic Naknek Formation, as mapped by Detterman and others (1987). The Naknek is rich in plutonic detritus shed from the Jurassic arc batholith complex (fig. 6A), and thus is likely to yield a strong positive aeromagnetic signature. Detterman and others (1987) also mapped a narrow, continuous strip of Middle Jurassic Shelikof Formation in the low hills at the base of much higher and steeper terrain just east of Ugashik Narrows (fig. 3). We tentatively confirm the presence of Shelikof Formation in this area (fig. 6B), based on our observations of basaltic conglomerate beds in sandstones that bear a diverse molluscan assemblage, including the diagnostic Callovian ammonite Cadoceras in addition to broad-ranging bivalves and belemnites (R. Blodgett, oral commun., August 12, 2007). Detterman and others (1987) portrayed this sliver of Shelikof Formation as a horse caught between two apparently steep faults, both marked by parallel, solid lines. The Shelikof is juxtaposed against Bear Lake Formation at the western fault (down-to-west) and against Naknek Formation at the eastern fault (up-to-west). We found much less extensive bedrock exposure of the Shelikof than mapped previously, and we found no exposures of either of the two faults, but corresponding topographic lineaments are consistent with this structural interpretation for the Ugashik Narrows area.

\section{RELATIONSHIPS OF CONTACTS TO AEROMAGNETIC BOUNDARIES}

We recognize that aeromagnetic anomalies do not necessarily closely coincide with the distribution of buried magnetic bodies (e.g., Vacquier, 1963). However, in certain cases, the correlation between well-defined magnetic anomalies and exposed bedrock units is compelling enough to warrant fairly literal interpretation of the shallow subsurface. For example, Saltus and others (2001) filtered a high-resolution aeromagnetic dataset in the Tertiary Cook Inlet basin at various wavelengths, and successfully related the shorter wavelength anomalies 
to structurally-defined geologic contacts at or very near the surface.

Where faults of the ULFS are constrained by outcrop, they coincide closely with two sharply-defined strands of alternating high and low magnetic intensity in the unfiltered aeromagnetic map of figure 4 (Saltus and others, 1999; Meyer and others, 2004; Meyer, 2007). These bands define a pair of arcuate, northeast-trending, short-wavelength magnetic anomalies. The eastern strand extends farther north than the western strand, intersecting the Becharof discontinuity at Gas Rocks on the south shore of Becharof Lake, and runs south near the east shore of Upper and Lower Ugashik lakes.
The western anomaly terminates northward just west of Upper Ugashik Lake, passes just west of Ugashik Narrows, and merges with the eastern anomaly in the uplands south of Lower Ugashik Lake. This merged band of high magnetic intensity continues southwest for at least $75 \mathrm{~km}$ (50 mi) as a fairly well-defined linear feature (fig. 4).

Many of the Jurassic and younger sedimentary formations on the Alaska Peninsula possess significant magnetic susceptibility due to the presence of magnetite and/or other magnetic minerals derived from the Jurassic, Tertiary, and Quaternary magmatic arcs. Where exposed in the Ugashik Lakes area, Jurassic Naknek
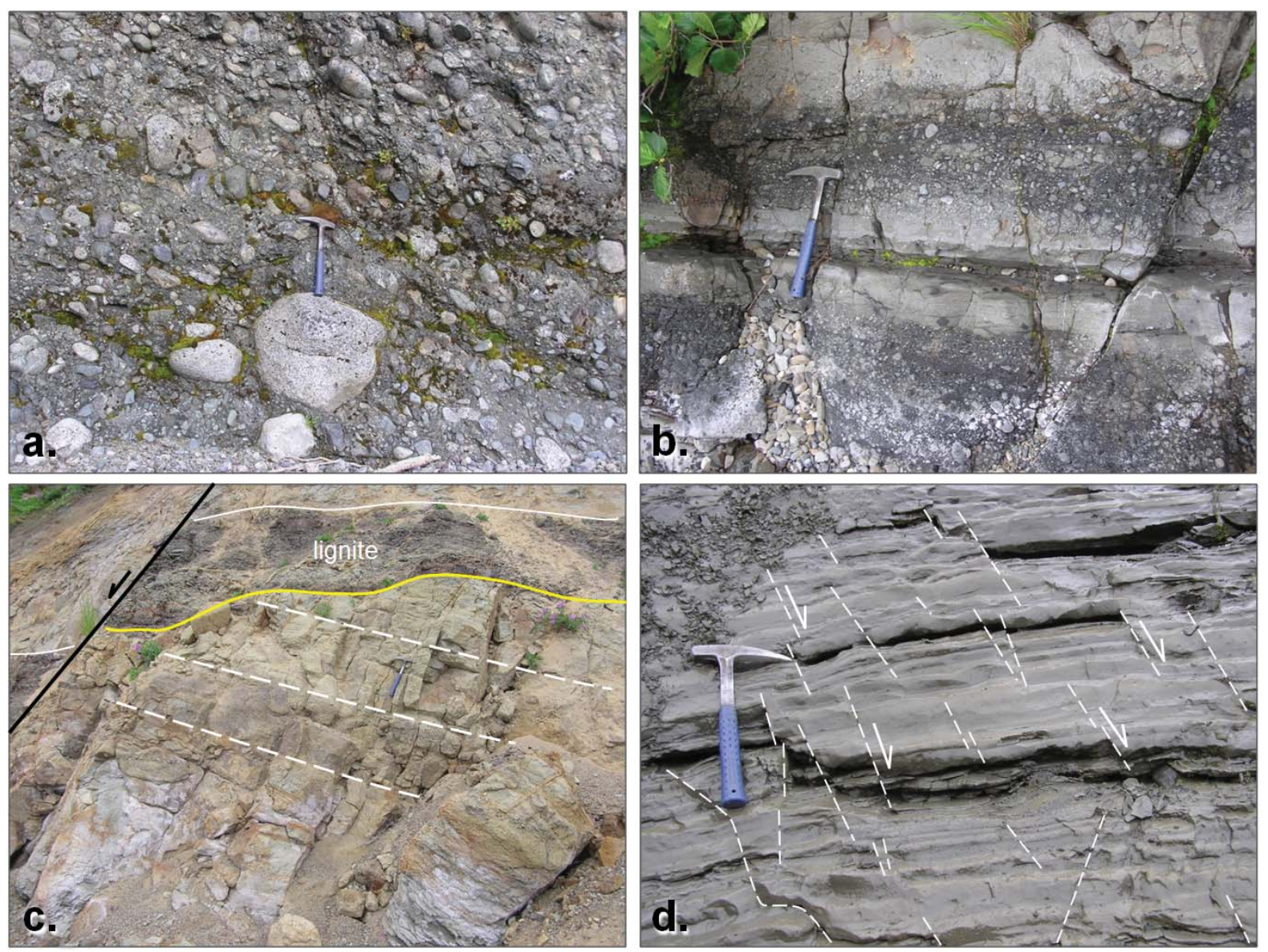

Figure 6. Field photographs of rock units in the vicinity of the Ugashik Lakes fault system (see figure 3 for station locations). Hammer for scale in all photos. (A) Naknek Formation conglomerates with abundant plutonic cobbles and boulders on shoreline of island in Upper Ugashik Lake at station 07PD151. (B) View looking downward at moderately east-dipping sandstone and basaltic conglomerate beds in Shelikof Formation on east shore of Upper Ugashik Lake north of station 07PD154. This unit contains abundant magnetic minerals within basaltic clasts and as detrital heavy mineral grains. (C) View to east-southeast of Bear Lake Formation conglomeratic sandstone and lignite north of Ugashik Narrows on the east shore of Upper Ugashik Lake at station 07PD154. Syndepositional fault rotation is implied by intraformational truncation of sandstone beds below lignite horizon. Both units are offset by later down-to-north fault at left, one of numerous minor northwest-striking faults exposed in outcrops in this area. (D) View to southwest of abundant penecontemporaneous microfaults and shear fractures in lightly consolidated lacustrine(?) silt of Bear Lake Formation south of Lower Ugashik Lake at station 07PD173. 
and Shelikof outcrops consistently underlie the eastern band of strongly positive magnetic signature. This is particularly clear along the eastern shorelines of Upper and Lower Ugashik lakes, for example, immediately east of the Ugashik Narrows (figs. 4 and 7). The outcrops of Bear Lake Formation occur within bands of negative magnetic signature between and to the west of the positive lineaments. Bear Lake outcrops near Ugashik Narrows are bounded by linear, highly positive strands on both east and west, whereas Bear Lake outcrops south of Lower Ugashik Lake occur west of the intersection of the two positive strands. Continuing farther southwest, the merged, single-stranded positive anomaly corresponds mainly with outcrops of Eocene-Oligocene Meshik volcanics (fig. 7).

Where exposure is sufficient to map with reasonable confidence (particularly near the Ugashik Narrows), the fault contacts between Bear Lake and Jurassic units occur at fairly obvious, qualitatively assessed boundaries between relatively short-wavelength positive and negative aeromagnetic anomalies. We infer from this that the aeromagnetic boundaries can, in fact, be used to extend these rock units and fault traces into areas of thin surficial cover. The magnetic patterns imply that there are likely two major faults that accommodated or preserved Bear Lake deposits on their western downthrown blocks (labeled A and B in figs. 8 and 9). According to the conceptual model of figure 9, Bear Lake outcrops near the Ugashik Narrows are preserved on the downthrown side of the eastern fault (A). This fault contact is inferred to continue northward, immediately west of the island of Naknek conglomerates in Upper Ugashik Lake. The Bear Lake outcrops south of Lower Ugashik Lake are likely downthrown to a separate western fault (B) parallel to the western magnetic boundary. Shown in figure 8, this model revises the mapping of Detterman and others (1987), which connected the Bear Lake fault contacts north and south of Lower Ugashik Lake with a single fault trace (fig. 3), despite the fact that it cuts obliquely across the well-defined, banded magnetic anomalies (fig. 7). Future geologic mapping in the Ugashik Lakes region may benefit from the computation of horizontal gradients and identification of linear features from the aeromagnetic data (e.g., linear maximum gradient analysis of Saltus and others, 2001) to define magnetic boundaries and locate covered fault contacts with greater precision.

\section{STRUCTURAL FABRIC}

Lacking exposures of the controlling faults themselves, we collected orientation data on fracture and minor fault planes from Jurassic and Tertiary outcrops at five locations in and near the ULFS, listed from north to south in table 1 and located on the map of figure 3 . Between 41 and 66 planes were measured at each station to shed light on the orientation, variability, and kinematic history of faults in the zone, and to weigh the hypothesis that its major structures are westerly-dipping normal faults. Slickenlines, fault steps, and other measurable indicators of true slip direction were unfortunately rare. Evidence for normal stratigraphic separation is much more common than reverse separation, but the lack of true slip indicators made it difficult to assess the magnitude of potential strike-slip.

Figure 10 shows fabric diagrams summarizing the attitudes of planes from each measurement station. Lower hemisphere stereographic projections illustrate the variations in both strike and dip of fractures and minor fault planes. Superimposed rose diagrams provide a quick statistical comparison of the dominant fracture strike orientations; the outer circle represents 15 percent of the data in each population. All five stations show multiple fault and fracture sets, and in four of the five datasets, one strike orientation dominates over the others, though the dominant orientation varies with location. Steep, north-northeast-striking planes form a recognizable or predominant set in all but the southernmost station; in most cases, fractures of this strike dip toward the west-northwest. We interpret these as minor faults and associated shear fractures parallel (synthetic) to the major faults of the ULFS (i.e., we interpret the major faults as northwest-dipping). Planes with similar strike but dipping the opposite direction (east-southeast) are interpreted as antithetic faults and shear joints. In the contractionally-deformed Jurassic units (stations 07PD151, 07PD 161, and 07PD168), fractures with

Table 1. Fracture and minor fault measurement stations

\begin{tabular}{llll}
\hline Station & Formation & \multicolumn{1}{c}{ Lithology } & \multicolumn{1}{c}{ Location Description } \\
07PD151 & Naknek & Conglomerate, sandstone & Island in Upper Ugashik Lake \\
07PD154 & Bear Lake & Sandstone, siltstone, coal & Shoreline, northeast of Ugashik Narrows \\
07PD168 & Shelikof & Sandstone & Shoreline, southeast of Ugashik Narrows \\
07PD161 & Naknek & Conglomerate & Highland slope, south of Lower Ugashik Lake \\
07PD173 & Bear Lake & Silty sandstone & Upland stream, south of Lower Ugashik Lake \\
\hline
\end{tabular}


this orientation could plausibly relate to either reverse or normal faulting. In the Bear Lake Formation (stations 07PD154 and 07PD173), the preponderance of normal offsets indicates the fabric is extensional in origin (figs. 6C and D).
In the Bear Lake exposures north of the Ugashik Narrows at 07PD154, minor normal faults have two predominant attitudes (fig. 10). Measurements there may have been statistically biased by the north-northeast trend of the bluff face-parallel to the controlling faults

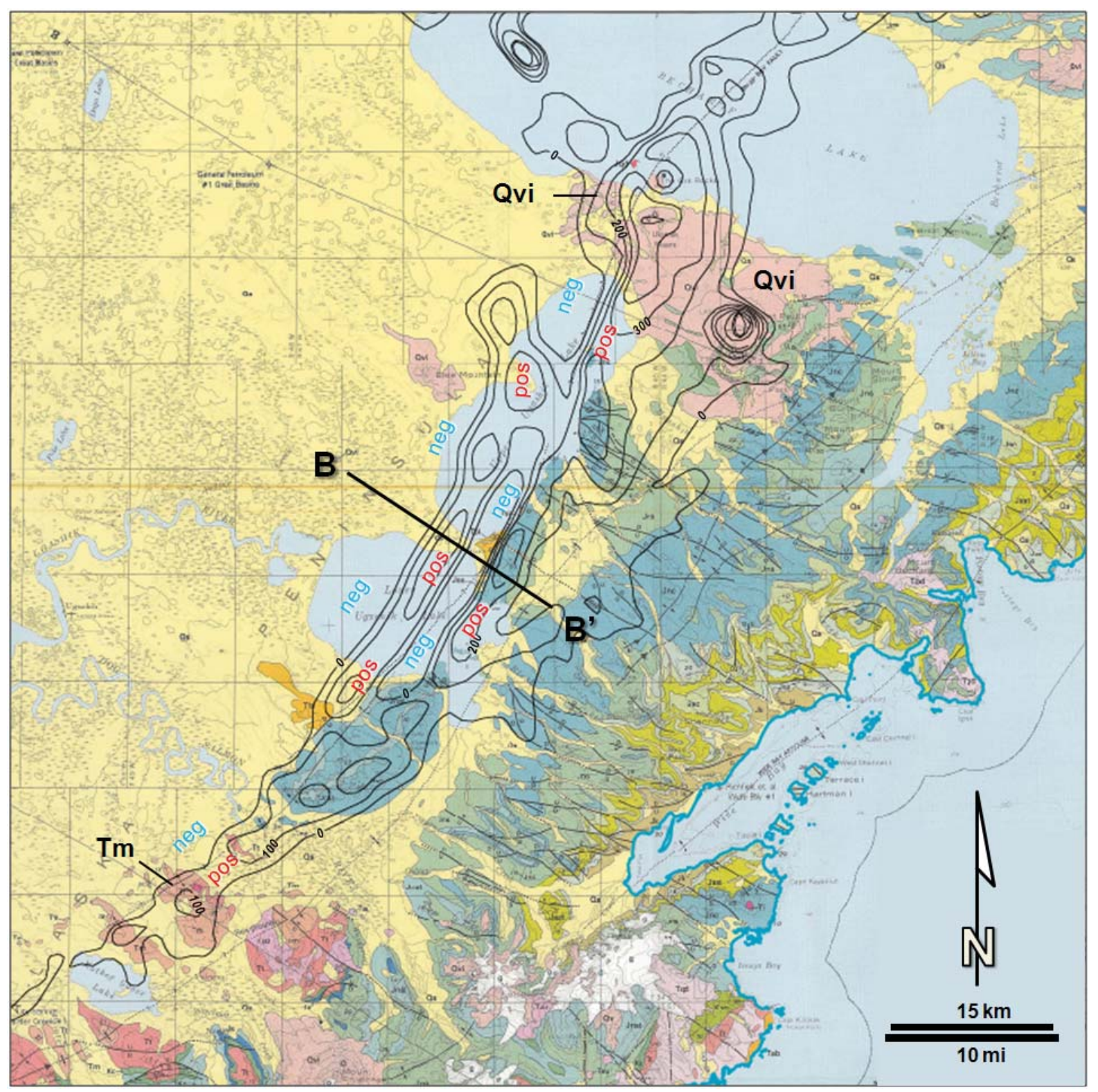

Figure 7. Excerpt from geologic map of Detterman and others (1987) overlain by contours of positive aeromagnetic anomalies most relevant to the Ugashik Lakes and Bruin Bay fault systems (contour interval $100 \mathrm{nT}$, outside contour $=0 \mathrm{nT}$ ) from Meyer and others (2004) after Saltus and others (1999). Bear Lake Formation exposures occur in bands of negative total magnetic intensity (labeled “neg”). Band of positive magnetic intensity (labeled "pos”) along the east shore of the Ugashik Lakes corresponds to Jurassic exposures. To the north between Upper Ugashik Lake and Becharof Lake, this positive anomaly is complicated by Quaternary volcanics and shallow intrusive bodies associated with Mount Peulik volcano, The Gas Rocks, and Ukinrek Maars (Qvi). In the southwestern part of the map, the positive magnetic anomaly relates mainly to outcrops of Meshik volcanics (Tm). Line B-B' shows location of schematic model in figure 9. See figure 3 for more geologic detail in Ugashik Lakes area. 
of the ULFS—but down-to-northeast, northwest-striking faults are abundant in this outcrop, and exhibit evidence of syndepositional movement (fig. 6c). Detterman and others (1987) mapped numerous northwest-striking cross faults in the folded Mesozoic rocks east of the Ugashik Lakes. Fractures and normal faults of this general orientation having displacements on the decimeter to meter scale are abundant in the outcrops we visited (e.g., in the Shelikof Formation at station 07PD168, and in the Bear Lake Formation at station 07PD154, fig.10), recording Miocene or younger arc-parallel extension in addition to subsidence of the backarc basin itself. Other planes of similar strike are nearly vertical (or perpendicular to bedding). In Mesozoic units, some of these may represent extension joints formed during earlier contractional deformation.

At the southernmost station south of Lower Ugashik Lake (07PD173), the Bear Lake Formation consists of finely layered, locally contorted, lightly consolidated silty claystones interpreted as lacustrine deposits. These beds are cut by numerous discontinuous shear planes that have a strong preferred orientation with east-northeast $\left(\sim 070^{\circ}\right)$ strike and steep north-northwest dip. These planes are conspicuous in outcrop as closely spaced microfaults with down-to-northwest normal displacement of approximately 1-2 cm (fig. 6D). Many of these shears die out into small-scale drag folds, consistent with faulting of semi-consolidated sediments. The attitude and characteristics of these structures are consistent with syndepositional Neogene subsidence in the area of the Ugashik sub-basin west of Ugashik Lakes. A fracture set with similar attitude is apparent in the nearby Naknek Formation (fig. 10, station 07PD161), suggesting similar extensional stresses also affected the much more indurated Mesozoic rocks near the ULFS in the area.

Due to widespread cover in the hills south of Lower Ugashik Lake, we were unable to determine the precise location of any significant faults of the ULFS between the Bear Lake and Naknek exposures just described, notwithstanding the solid fault trace shown in previous

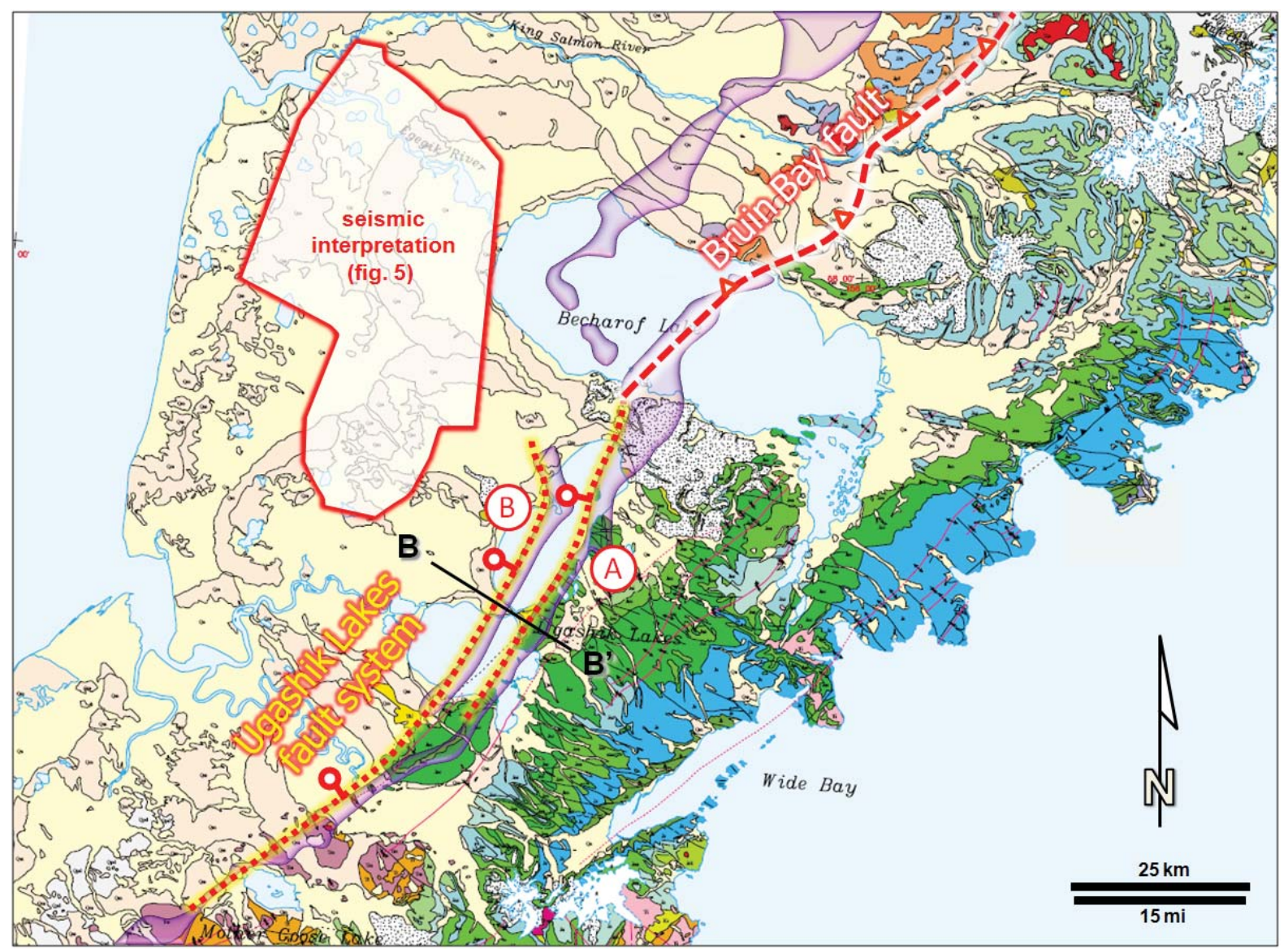

Figure 8. Map showing the reinterpreted traces for the mostly covered controlling faults of the Ugashik Lakes fault system as yellow-highlighted dotted traces (bar and ball on downthrown side). Trace of the Bruin Bay fault is white-highlighted dashed trace (teeth on upthrown side). Strongly positive short-wavelength aeromagnetic anomalies are generalized here as transparent purple areas. Line B-B' refers to the conceptual model of figure 9. 


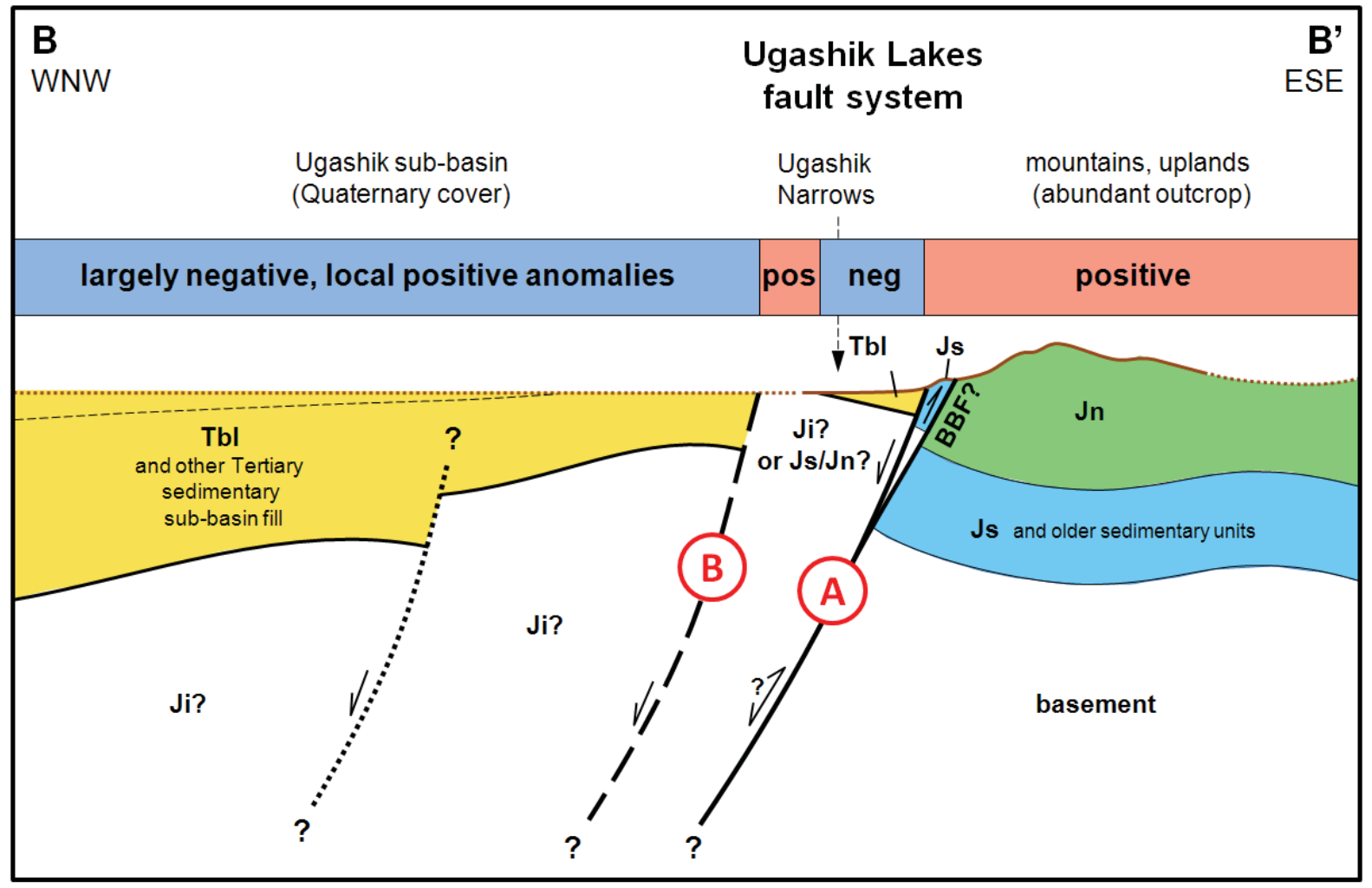

Figure 9. Conceptual model showing relationship of aeromagnetic anomaly pattern to inferred bedrock structure along line $B-B$ 'shown in figures 7 and 8. Surface profile is represented by dotted brown line where bedrock is completely obscured by surficial cover (unknown thickness not represented). Tertiary Bear Lake Formation (Tbl) outcrops coincide with negative magnetic anomalies; Jurassic Naknek (Jn) and Shelikof (Js) exposures coincide with strong positive anomalies. Jurassic batholith (Ji) is probable basement west of ULFS. Faults labeled A and B discussed in text; "BBF?" fault may be a relict segment of the reverse-displacement Bruin Bay fault, and may merge with fault A at depth. Additional down-to-northwest faults in Ugashik sub-basin inferred from seismic data. Not to scale.

mapping (Detterman and others, 1987; Wilson and others, 1999). We did locate a previously unmapped, intermediate-composition porphyritic dike in the general area where the fault(s) would be expected; this dike has been added to the map in figure 3 . The dike itself is erosionally resistant, forming a ridge that trends $070^{\circ}$, but we found no nearby bedrock of the intruded sedimentary unit(s). Detterman and others (1987) mapped this ridge as Bear Lake Formation, placing the main fault nearby to the southeast. The dike has not been radiometrically dated, and without certainty as to which formation(s) it intrudes, we are unable to constrain its age beyond post-Late Jurassic. However, its strike-parallel to the Neogene extensional fabric in the nearest Bear Lake outcrop-suggests a genetic link to the north-northwest/south-southeast extension direction in the ULFS in this area. It is possible that the dike intruded during extensional movement along the surface of one of the system's significant faults.

\section{SUMMARY OF FINDINGS ON THE UGASHIK LAKES FAULT SYSTEM}

Our field observations confirm the overall distribution of Jurassic and Tertiary bedrock units as mapped by Detterman and others (1987) and Wilson and others (1999) in the vicinity of Ugashik Lakes, though we disagree locally with the continuity of exposure shown in their maps. Our integration of the aeromagnetic data (Saltus and others, 1999; Meyer and others, 2004; Meyer, 2007) suggests the ULFS consists of at least two poorly exposed faults that have a different and more extensive map expression than shown on existing geologic maps. Fabric populations indicate a variety of fault and fracture trends that are consistent with the controlling faults of the ULFS being steep, northwest-dipping normal or normal-oblique faults.

Just east of Ugashik Narrows, Detterman and others' (1987) interpretation of two parallel, closely spaced, north-northeast-striking faults with opposite senses of displacement (fig. 3) is a viable explanation of the bedrock map units there, but we were unable to locate 


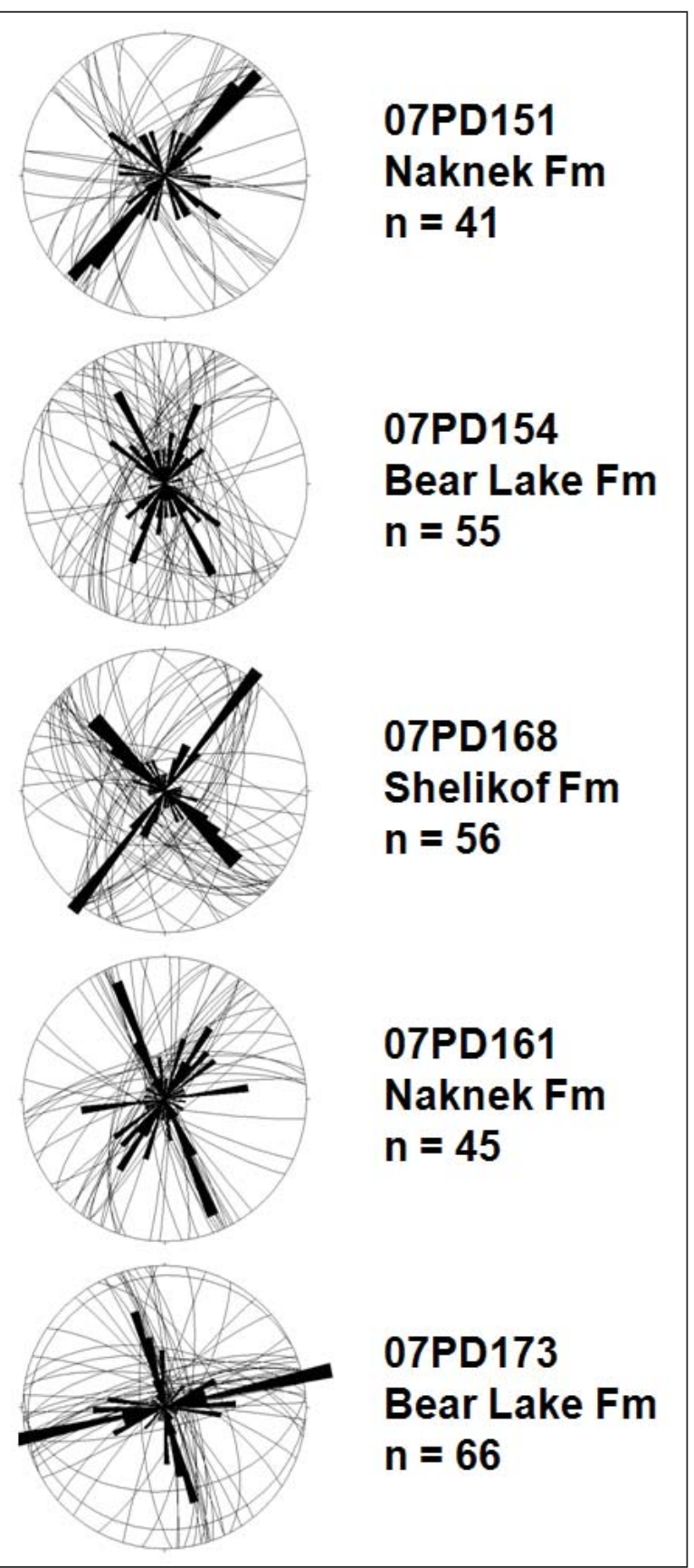

Figure 10. Structural fabric diagrams of fractures and minor faults in the vicinity of the Ugashik Lakes fault system. Stations are arranged from north at the top to south at the bottom; locations are shown in figure 3. Lower hemisphere stereographic projections show strike and dip of planes. Superimposed rose diagrams show their strike and relative abundance; outer circle represents 15 percent of the population in each plot. any exposures of these fault surfaces to document their attitude or examine them for kinematic indicators. The eastern of these two faults has a component of up-towest displacement, placing a sliver of Middle Jurassic Shelikof Formation against Upper Jurassic Naknek Formation (fig. 3). Its dip is not well constrained, but as an up-to-west fault, it may be closely related to the Bruin Bay reverse fault system, and may represent its southernmost relict surface trace. Thus, it is possible that the down-to-west faults of the ULFS represent a down-to-west extensional (or transtensional) reactivation of the up-to-west compressional (or transpressional) system. The western of the two faults mapped near Ugashik Narrows (fault A in figs. 8 and 9) is clearly down-to-west. It marks Miocene or younger faulting that accommodated and/or preserves the northeasternmost occurrences of Bear Lake Formation. The eastern short-wavelength magnetic anomaly coincides closely with the fault contact between Tertiary strata on the west and Jurassic rocks on the east.

The outcrops of Bear Lake Formation south of Lower Ugashik Lake are also believed to be bounded by one or more normal faults, but this contact coincides more closely with the south end of the western short-wavelength magnetic anomaly. We interpret it as a separate western fault strand (B in figs. 8 and 9), distinct from either of the two faults near Ugashik Narrows, whereas Detterman and others (1987) connected the two Bear Lake fault contacts with a dotted line that cut obliquely across the banded magnetic anomalies in Lower Ugashik Lake. East-northeast-trending, down-to-northwest microfaults in the southern Bear Lake outcrops document Miocene or younger extension that would allow subsidence of the Ugashik sub-basin. A nearby dike with nearly the same strike as the Bear Lake microfaults may be genetically linked to this subsidence. Better knowledge of the age and spatial relationship of this dike to the unexposed fault contact nearby could be important in documenting the age and kinematics of the ULFS.

The amount and sense of strike-slip along the ULFS is not well constrained by our investigations. Most of the regional fault systems in southern Alaska are believed to have major right lateral offsets, but Detterman and Hartsock (1966) interpreted the offset of Mesozoic contacts in the Lower Cook Inlet region as evidence the Bruin Bay fault may have had up to 19 $\mathrm{km}$ (12 mi) of left lateral movement during middle to late Tertiary time. The Bruin Bay fault intersects the right-lateral Lake Clark/Castle Mountain fault system at an angle of more than $30^{\circ}$, and it may represent an antithetic (conjugate) structure with the opposite sense of strike-slip. Furthermore, most of the available focal mechanism solutions for recent earthquakes imply generally north-south-oriented maximum compressive stress in the Becharof-Ugashik Lakes region 


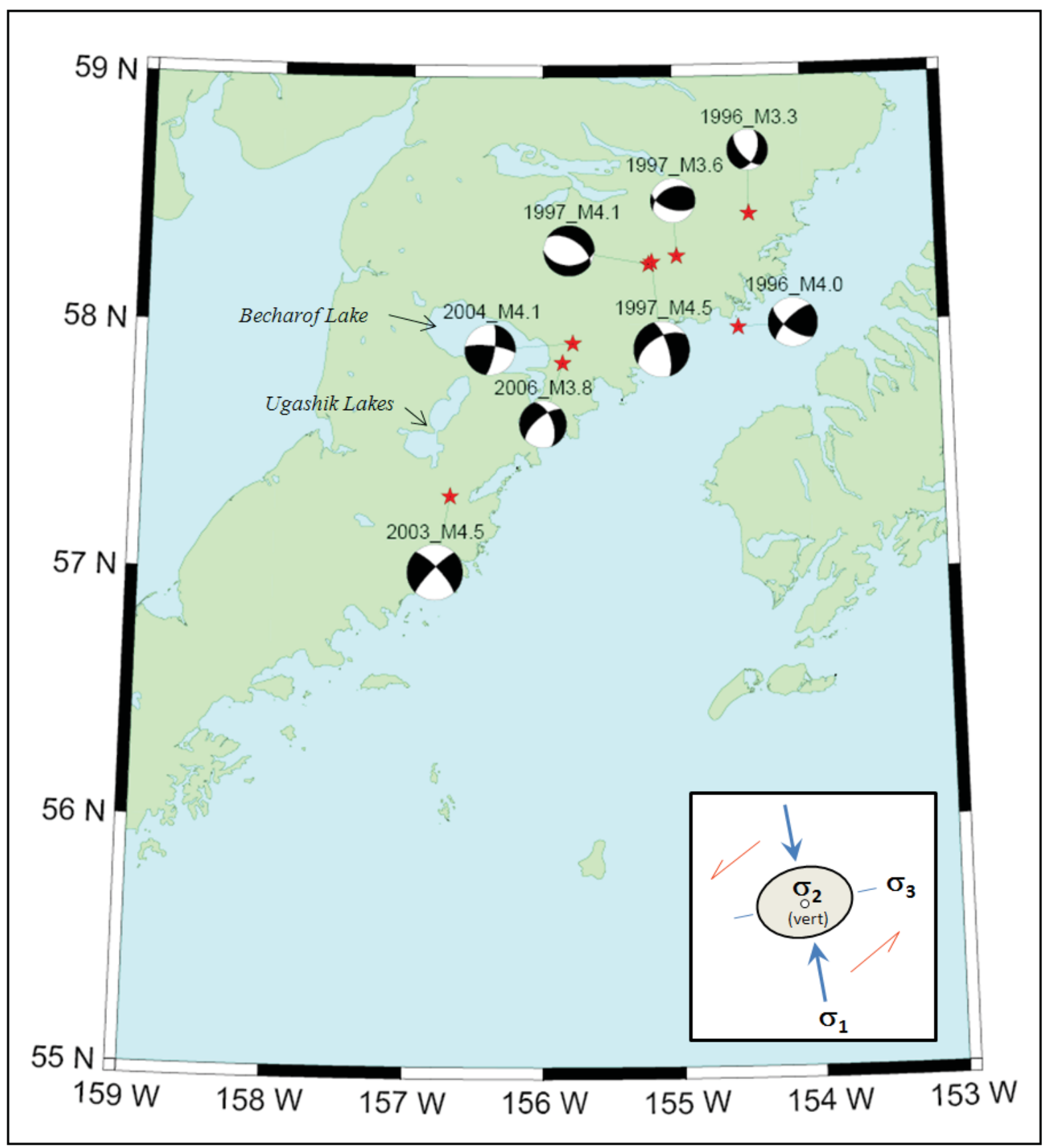

Figure 11. Focal mechanisms in the northern Alaska Peninsula region spanning the years 1996-2006. All the events shown are located southeast of both the Ugashik Lakes and Bruin Bay fault systems. Several epicenters coincide closely with Holocene volcanoes in the Katmai area. Most of these events are consistent with a large component of either left lateral strike-slip on northeast-striking faults or right lateral strike-slip on northwest-striking cross faults, with a generally north-south-trending, subhorizontal axis of maximum compressive stress $\left(\sigma_{H}=\sigma_{1}\right.$, bisecting white quadrants), subvertical intermediate stress $\left(\sigma_{v}=\sigma_{2}\right)$, and subhorizontal, generally east-west-trending minimum compressive stress $\sigma_{h}=\sigma_{3}$. Plot courtesy of Natalia Ruppert, Alaska Earthquake Information Center. 
(fig. 11; N. Ruppert, written commun., June 11, 2007). If similar stress orientations existed during middle to late Tertiary movement on the northeast-southwest-trending Bruin Bay and Ugashik Lakes fault systems, it would have favored a component of sinistral slip.

\section{NEOGENE KINEMATIC MODEL}

\section{SUBSIDENCE HISTORY OF THE UGASHIK SUB-BASIN}

As alluded to in a previous section, well correlations indicate that the northeastern end of the North Aleutian basin-the Ugashik sub-basin-has a younger subsidence history than the main backarc depocenter, and is separated from it by an extensive volcanic center in the area of the Port Heiden 1 and Ugashik 1 wells. This subbasin is illustrated at the right (northeast) end of Sheet 1 , a structurally datumed well log correlation panel that extends northeast from the heart of the backarc at the North Aleutian Shelf COST 1 well to the Great Basins 2 well west of Becharof Lake (fig. 1A). Formation tops and internal correlation markers used in these correlations are guided by a combination of biostratigraphic control (Mickey and others, 2005) and well log character.

The offshore North Aleutian COST 1 well was deliberately drilled in a structural low to penetrate as much stratigraphic section as possible, including thick intervals of Eocene Tolstoi and Eocene to Early Oligocene Stepovak Formations deposited during the early stages of backarc subsidence. Wells drilled onshore to the east and northeast penetrated the basin closer to its southern edge, where the Tolstoi thins and pinches out. The volcaniclastic deposits of the Stepovak maintain a thickness of $\sim 1,400 \mathrm{~m}(4,500 \mathrm{ft})$ offshore to $\sim 1,800 \mathrm{~m}(6,000 \mathrm{ft})$ onshore at the Sandy River 1 well before interfingering to the northeast (proximally) with primary lavas of the Meshik volcanics. These lavas are structurally elevated and reach a thickness of at least 1,800 m (6,000 ft) in the vicinity of the Port Heiden 1 and Ugashik 1 wells, interpreted as the locus of Oligocene extrusive activity (Sherwood and others, 2006).

The Ugashik sub-basin lies northeast of this Meshik high, in the area penetrated by the Becharof 1 and Great Basins 1 and 2 wells (sheet 1). Lacking any biostratigraphic evidence for pre-Tertiary sedimentary units, Mickey and others (2005) interpreted the basal strata in the area as uppermost Stepovak Formation volcaniclastics, presumably shed from the Meshik volcanic complex to the southwest. Consisting of nonmarine to marginal marine conglomerate, sandstone, and coal, this interval ranges from 0 to $400 \mathrm{~m}(0-1,400 \mathrm{ft})$ thick, implying that accommodation remained limited here through Oligocene time. Compelling log correlations in these three wells show differential thickening of the lower Bear Lake Formation in Great Basins 1, the well nearest the center of the sub-basin. Log markers and biostratigraphic picks indicate more uniform thicknesses in the upper Bear Lake and the overlying Pliocene Milky River Formation (sheet 1), constraining the phase of major differential subsidence to a brief span of Miocene time.

\section{FAULT CONTROLS ON UGASHIK SUB-BASIN SUBSIDENCE}

Seismic mapping northwest of Ugashik Lakes and southwest of the Becharof discontinuity indicate an important element of fault control on the Ugashik subbasin. Figure 5 is a preliminary structure contour map (contoured in seismic two-way time) near the base of the base Bear Lake Formation. An interpretation of the publicly available ANM and ARD seismic surveys (Alaska Division of Oil and Gas, 2004), it covers a limited area of the coastal plain at, and southwest of, the Becharof discontinuity, well to the west of Ugashik Lakes. The most conspicuous features of this seismic interpretation are (1) a west-northwest-trending structural low with a maximum two-way travel time of more than 3 seconds, estimated at more than 4,350 $\mathrm{m}(14,300 \mathrm{ft})$ deep, and (2) northwest- and west-northwest-trending faults that appear to have controlled subsidence into this trough. A faulted zone of steep structural gradient rises from this low on the northeast side up to less than 1.4 seconds, equivalent to approximately $1,500 \mathrm{~m}(5,000 \mathrm{ft})$. This structural gradient coincides closely with the magnetic gradient and other features that define the northwest trend and location of the Becharof discontinuity.

Most of the seismically imaged faults along the Becharof discontinuity offset reflections in the Bear Lake Formation, but only occasionally persist upward into the Pliocene Milky River Formation. As such, they reflect a component of extension parallel to the arc during Miocene time, and are presumably linked genetically to the outcrop-scale cross faults we observed in the Bear Lake Formation near the Ugashik Narrows, and to the numerous cross faults mapped by Detterman and others (1987) in the Mesozoic units east of the Ugashik Lakes. Modern seismicity, (McGimsey and others, 2003), the Ukinrek Maars phreatomagmatic eruptions (Barnes and McCoy, 1979; Motyka and others, 1993), the venting of mantle-derived CO2 at Gas Rocks (Symonds and others, 1997), and evidence of inflation of Mount Peulik volcano (C. Nye, written commun., January 18, 2007), suggest that the Becharof magnetic discontinuity has been a zone of weakness in the upper lithosphere since at least Miocene time, and that subsidence of the northeast margin of the Ugashik sub-basin may continue today.

We consider the ULFS the southeastern margin of the Ugashik sub-basin. Faults with north-northeast trends similar to that of the northern part of the ULFS 
are essentially absent from the seismic interpretation (fig. 5), but may be present east of the seismic survey, closer to Ugashik Lakes. The seismic interpretation indicates a series of arcuate faults near the south end of the dataset that strike east-northeast and are downthrown to the northwest. These faults appear to reflect the same extension as the microfault fabric in the Bear Lake Formation lacustrine deposits at station 07PD173 (fig. 10) and the dike nearby in the uplands south of Lower Ugashik Lake.

Field evidence for mid to late Tertiary left lateral strike-slip on the Bruin Bay fault (Detterman and Hartsock, 1966; Detterman and others, 1976; Detterman and Reed, 1980) is highly relevant to subsidence of the Ugashik sub-basin. This is particularly true in recognition of the Becharof discontinuity as a Neogene tectonic element that can explain the mechanical decouplingand thus the contrasting orientations and movement directions - between the linear, up-to-northwest Bruin Bay fault and the arcuate, down-to-northwest faults of the ULFS. If regional stress orientations were similar during the Neogene to those suggested by recent focal mechanism solutions, movement on the Bruin Bay fault should have been sinistral-reverse, as has been described. However, in a sinistral displacement field, the jog in fault trends at the Becharof discontinuity would become a left-stepping releasing bend, and the ULFS on the eastern side of the sub-basin can be readily interpreted as a transtensional or pull-apart margin (fig. 12). Under such a stress regime, these tectonic elements may have interacted to allow sinistral-reverse transpression north of Becharof Lake coeval with major Neogene subsidence in the adjacent Ugashik sub-basin.

\section{CONCLUSIONS}

Our field investigations in the Ugashik Lakes area corroborate certain critical outcrop relationships represented on USGS geologic maps, but we propose that the traces of two main faults in the Ugashik Lakes fault system should be interpreted differently in covered areas (mostly below the lakes themselves) to more closely follow the contours of curvilinear, short-wavelength aeromagnetic anomalies. Where constrained by outcrop,

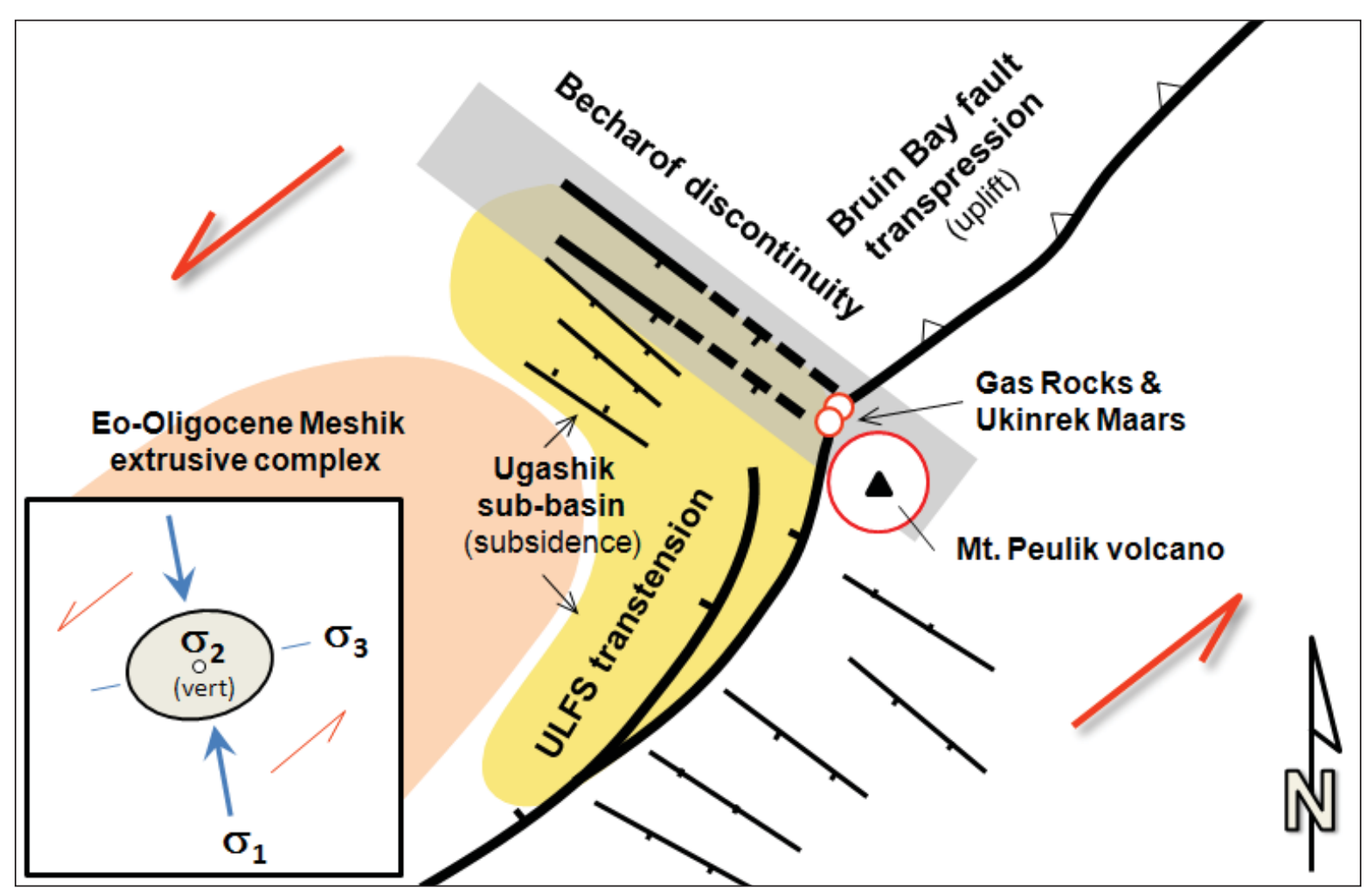

Figure 12. Cartoon of possible structural linkage of the Bruin Bay fault, the Ugashik Lakes fault system, the Ugashik subbasin, and the Becharof discontinuity. Critical geometries include the jog in fault trends and cross faults at the Becharof discontinuity. Neogene stress orientations similar to the modern regime inferred from the majority of focal mechanism solutions would have induced a left-lateral shear couple consistent with reverse-oblique movement (transpressive uplift) on the Bruin Bay fault, normal-oblique movement (transtension) along ULFS, and pull-apart subsidence of the Ugashik sub-basin. Refer to figure 11 for explanation of stress axes. 
the bands of negative magnetic intensity correspond with the Miocene Bear Lake Formation, containing sediments of mostly non-igneous origin; narrow bands of strongly positive magnetic intensity correspond to the Jurassic Naknek and Shelikof and Tertiary formations, which contain abundant detritus from the Jurassic magmatic arc. Where most sharply defined, the boundaries of these narrow magnetic anomalies coincide with mapped faults having Bear Lake Formation in the downthrown western blocks, and we consider it likely that the same holds true where these fault traces are obscured by the lakes and surficial cover.

Measurements of fractures and outcrop-scale faults along the ULFS define a complex fabric that at most stations includes prominent sub-populations of steep, west-northwest-dipping planes considered to mimic the attitude of the fault system's major north-northeast-striking structures. We thus interpret the controlling faults of the ULFS as west-northwest dipping with a significant component of normal displacement, rather than as eastsoutheast-dipping thrust or reverse faults. Accordingly, planes with similar strike but steep east-southeast dip probably represent genetically related antithetic shears. Subpopulations corresponding to northwest-striking minor faults reflect Miocene or younger arc-parallel extension.

An early phase of reverse movement on the Bruin Bay fault may have persisted at least as far south as the Ugashik Narrows, where a sliver of Middle Jurassic Shelikof Formation is juxtaposed by faulting with Upper Jurassic Naknek Formation. Elsewhere south of Becharof Lake, evidence for up-to-northwest movement related to the Bruin Bay fault has been erased by down-to-northwest movement on the ULFS, perhaps largely due to reactivation of pre-existing faults. South of Lower Ugashik Lake, the Bear Lake Formation hosts a dominant set of fractures and microfaults that dip steeply north-northwest, striking east-northeast parallel to a prominent nearby dike; both the structural fabric and the dike are consistent with extensional subsidence of the Ugashik sub-basin to the northwest.

We identify the Becharof discontinuity as a significant zone of Neogene and younger weakness oriented transverse to the Alaska Peninsula. This tectonic element accommodates some amount of arc-parallel extension, and may account for the abrupt change in strike and stratigraphic separation between the Bruin Bay fault to the north and the Ugashik Lakes fault system to the south. The mantle-sourced volcanism and $\mathrm{CO} 2$ venting at the intersection of these faults and the Becharof discontinuity are evidence that, at least locally, this weakness may extend through the entire thickness of the crust. South of the Becharof discontinuity, well correlations and seismic interpretation define the subsurface structure of the Ugashik sub-basin, set apart from the main North Aleutian backarc basin by a structurally elevated volcanic center drilled in the Port Heiden 1 and Ugashik 1 wells. Differential subsidence of the sub-basin apparently began during Miocene deposition of the lower Bear Lake Formation. The sub-basin is bounded by cross faults of the Becharof discontinuity to the northeast, and presumably by faults of the ULFS to the southeast.

A component of left-lateral strike slip on the Bruin Bay and Ugashik Lakes fault systems during Tertiary time is consistent with geologic map patterns in the western Cook Inlet region and with the modern stress regime interpreted from recent earthquake focal mechanisms. Neogene cross faulting at the Becharof discontinuity may have severed the southern end of the Bruin Bay fault system and allowed the blocks to the north and south to respond independently to an oblique-slip regime. The left-stepping kink in the fault trends at this discontinuity between the Bruin Bay and Ugashik Lakes fault systems would favor transtensional subsidence in the Ugashik sub-basin west of the ULFS yet allow either earlier or coeval transpressional shortening on the Bruin Bay fault. This may have important implications for the type and orientations of potential subsurface hydrocarbon traps along the Alaska Peninsula margin of the North Aleutian basin, particularly within the Ugashik sub-basin at its northeast end. Additional studies of the timing, sense, and magnitude of movement on the Bruin Bay fault would provide valuable constraints on this tectonic model.

\section{ACKNOWLEDGMENTS}

Field studies during 2007 were funded by the Alaska Division of Oil and Gas and the Alaska Division of Geological \& Geophysical Surveys. The text and figures benefited from the thorough and insightful reviews by Thomas Homza and Paige Delaney.

\section{REFERENCES CITED}

Alaska Division of Oil \& Gas, 2004, Alaska Peninsula areawide oil and gas lease sale and Bristol Bay basin exploration license area, information and data compilation: Alaska Division of Oil \& Gas, Alaska Peninsula oil and gas resource series, 3 volume CD-ROM.

Barnes, I., and McCoy, G.A., 1979, Possible role of mantle-derived $\mathrm{CO}_{2}$ in causing two "phreatic" explosions in Alaska: Geology, v. 7, p. 434-435.

Beeman, W.R., Obuch, R.C., and Brewton, J.D., 1996, Digital map data, text, and graphical images in support of the 1995 National Assessment of United States Oil and Gas Resources: U.S. Geological Survey Digital Data Series DDS-35, 1 disk, http://pubs. usgs.gov/dds/dds-035/DDS-35.html 
Detterman, R.L., and Hartsock, J.K., 1966, Geology of the Iniskin-Tuxedni region, Alaska: U.S. Geological Survey Professional Paper 512, 78 p., 6 plates, scale 1:63,360.

Detterman, R.L., and Reed, B.L., 1980, Stratigraphy, structure, and economic geology of the Iliamna Quadrangle, Alaska: U.S. Geological Survey Bulletin 1368-B, 86 p., 1 plate, scale 1:250,000.

Detterman, R.L., Case, J.E., Wilson, F.H., and Yount, M.E., 1987, Geologic map of the Ugashik, Bristol Bay, and western part of Karluk quadrangles, Alaska: U.S. Geological Survey Miscellaneous Investigations Series Map 1685, 1 plate, scale 1:250,000.

Detterman, R.L., Hudson, Travis, Plafker, George, Tysdal, R.G., and Hoare, J.M., 1976, Reconaissance geologic map along Bruin Bay and Lake Clark faults in Kenai and Tyonek quadrangles, Alaska: U.S. Geological Survey Open-File Map 76-477, 4 p., 1 plate.

McGimsey, R.G., Neal, C.A., and Girina, O., 2003, 1998 volcanic activity in Alaska and Kamchatka: summary of events and response of the Alaska Volcano Observatory: U.S. Geological Survey Open-File Report 03-423, 35 p.

Meyer, J.F., Jr., 2007, Total intensity magnetic anomaly for the Bristol Bay region and Alaska Peninsula: Alaska Department of Natural Resources, Division of Oil \& Gas, Alaska Peninsula Oil and Gas Field Map Series, plate 3 of 3, scale 1:500,000.

Meyer, J.F., Jr., Hansen, J.J., Brizzolara, D.W., Pritchard, M.E., Boggess, P.L., Beaty, C.J., Dirks, K.L., Gumpert, J.D., Bolin, K.A., Gibler, K.I., and Phillipson, E.M., 2004, Alaska aeromagnetic compilation, Ugashik quadrangle: Alaska Department of Natural Resources, Division of Oil \& Gas, Alaska Peninsula Resource Series, plate 10 of 19, scale 1:250,000.

Mickey, M.B., Haga, H. Boettcher, R.S., and Kling, S.A., 2005, Northwestern Alaska Peninsula-Bristol Bay basin biostratigraphy study: Micropaleo Consultants Job No. 25-104, 287 p., 4 oversize plates, 40 oversize figures, Alaska Division of Oil \& Gas online publication http://www.dog.dnr.state.ak.us/oil/ products/publications/akpeninsula/biostrat.htm
Molenaar, C.M., 1996, Thermal-maturity patterns and geothermal gradients on the Alaska Peninsula, in Johnsson, M.J., and Howell, D.G., eds., Thermal evolution of sedimentary basins in Alaska: U.S. Geological Survey Bulletin 2142, p. 11-19.

Motyka, R.J., Liss, S.A., Nye, C.J., and Moorman, M.A., 1993, Geothermal resources of the Aleutian Arc, Alaska: Alaska Division of Geological \& Geophysical Surveys Professional Report 114, 17 p.

Saltus, R.W., Connard, G.G., and Hill, P.L., 1999, Alaska aeromagnetic compilation-digital grids and survey data: U.S. Geological Survey Open-File Report 99-502, CD-ROM.

Saltus, R.W., Haeussler, P.J., Bracken, R.E., Doucette, J.P., and Jachens, R.C., 2001, Anchorage Urban Region Aeromagnetics (AURA) Project - preliminary geophysical results: U.S. Geological Survey OpenFile Report 01-0085, 21 p.

Sherwood, K.W., Larson, J., Comer, C.D., Craig, J.D., and Reitmeier, C., 2006, North Aleutian basin OCS planning area assessment of undiscovered technically-recoverable oil and gas: U.S. Minerals Management Service Alaska OCS Region report, 138 p., 4 plates, www.mms.gov/alaska/re/reports/rereport.htm

Symonds, R.B., Ritchie, B.E., McGimsey, R.G., Ort, M.H., Poreda, R.J., Evans, W.C., and Janik, C.J., 1997, Investigations of gas seeps and springs in the vicinity of The Gas Rocks, south shore Becharof Lake, Alaska: U.S. Geological Survey Open-File Report 97-0127, 27 p.

Vacquier, V., 1963, General principles, in Vacquier, V., Steenland, N. C., Henderson, R.G., and Zietz, I., Interpretation of aeromagnetic maps: Geological Society of America Memoir 47, 151 p., 14 plates.

Wilson, F.H., Detterman, R.L., and Case, J.E., 1985, The Alaska Peninsula terrane; A definition: U.S. Geological Survey Open-File Report 85-450, 17 p.

Wilson, F.H., Detterman, R.L., and DuBois, Gregory, 1999, Digital data for the geologic framework of the Alaska Peninsula, Southwest Alaska, and the Alaska Peninsula Terrane: U.S. Geological Survey OpenFile Report 99-317, 41 p., 1 plate, scale 1:500,000, http://wrgis.wr.usgs.gov/open-file/of99-317. 